\title{
Evaluation of Indigenous Fynbos and Renosterveld Species for Cover Crop Management in the Vineyards of the Coastal Wine Grape Region, South Africa
}

\author{
J.C. Fourie \\ ARC Infruitec-Nietvoorbij ${ }^{1}$, Private Bag X5026, Stellenbosch, 7599 South Africa \\ Submitted for publication: September 2013 \\ Accepted for publication: October 2013
}

Key words: Biodiversity, grapevines, cover crops, indigenous species, soil cultivation

\begin{abstract}
Four treatments in which fynbos and renosterveld species were employed as cover crops, and two treatments in which exotic species were used as cover crops, were applied. A treatment in which indigenous annuals and an exotic annual was sown as mixture, and a control in which no cover crop was established, were also included in the trial. These eight treatments were applied for four consecutive years on a sandy soil $\left(33^{\circ} 52^{\prime} \mathrm{S}, 1^{\circ} 58^{\prime} \mathrm{E}\right)$ and a sandy loam soil $\left(3^{\circ} 55^{\prime} \mathrm{S}, 1^{\circ} 52^{\prime} \mathrm{E}\right)$ in vineyards near Stellenbosch, South Africa. Effective suppression of the winter growing weeds was achieved with Avena sativa $\mathrm{L}$. cv. Pallinup on a sandy soil from the third season onwards. This was also achieved with a mixture of Ornithopus sativus $L$. cv. Emena (50\%) and three indigenous broadleaf annuals (50\%), namely Felicia heterophylla (Cass) Grau, Dimorphotheca pluvialis (L.) Moench and Scenecio elegans L. None of the renosterveld and lowland fynbos mixtures or monocultures had the ability to become established effectively on both the sandy and sandy loam soil, or could compete effectively with the winter-growing weeds commonly found in the vineyards of the Coastal wine grape region of the Western Cape. These species therefore should not be considered for cover crop management in this region.
\end{abstract}

\section{INTRODUCTION}

Approximately $90 \%$ of South African wines are produced within the boundaries of one of the most biologically diverse regions on earth, namely the Greater Cape Floristic Region (GCFR) (Goldblatt \& Manning, 2012). The GCFR is recognised internationally as a global biodiversity hotspot and listed as a world heritage site. The Core Cape Subregion of the GCFR encompasses four biomes (ecoregions), of which fynbos and renosterveld are the two most prominent ones (Goldblatt \& Manning, 2012). The expansion of urban and agricultural areas has reduced the available natural habitat of the fynbos and renosterveld. It therefore is important to determine whether fynbos and renosterveld species can be employed as cover crops in the grapevine inter-row in order to expand the range of these species. This may also serve as a unique selling point for South African wines on the overseas and local markets. However, the ability of these species to become established in the vineyard environment and compete with the exotic weeds present in vineyards is not known.

The aim of the study was to determine the performance and weed-suppressing ability of selected fynbos and renosterveld species when used as cover crops in vineyards established on sandy and sandy loam soils in the Stellenbosch district of the Coastal wine grape region of South Africa.

\section{MATERIALS AND METHODS}

Experimental vineyard and layout

The trial was conducted for four consecutive seasons (2006/07 to 2009/10) in a full-bearing Sauvignon blanc/ Richter 99 vineyard established on a sandy soil (Table 1) at Boschendal farm (335' $\left.\mathrm{S}, 18^{\circ} 58^{\prime} \mathrm{E}\right)$, and a full-bearing Cabernet Sauvignon/Richter 110 vineyard established on a sandy loam soil (Table 1) at Nietvoorbij research farm $\left(33^{\circ} 55^{\prime} \mathrm{S}, 18^{\circ} 52^{\prime} \mathrm{E}\right)$. Both farms are situated in the Stellenbosch district. Mean annual rainfall at Boschendal over the four years of the trial was $1543 \mathrm{~mm}$, of which $64 \%$ fell during autumn and winter (March to August). At Nietvoorbij the annual rainfall averaged $880 \mathrm{~mm}$, of which $71 \%$ fell during autumn and winter. The Sauvignon blanc vines were spaced $1.2 \mathrm{~m}$ in the row and $2.75 \mathrm{~m}$ between rows, and trained onto a Perold trellis system (Booysen et al., 1992), while the Cabernet Sauvignon vines were spaced

\footnotetext{
${ }^{1}$ The Fruit, Vine and Wine Institute of the Agricultural Research Council

*Corresponding author: E-mail address: FourieJ@arc.agric.za

Aknowledgements: The author thanks the ARC and Winetech, for financial support, the staff of Soil and Water Science at the ARC Infruitec-Nietvoorbij, for technical support, Rachel Saunders of Silver Hill Seeds, for helping with the selection of indigenous species, and Boschendal Wine Estate, for supplying one of the trial sites. The Cape seed primer ${ }^{\circledR}$ used is a product of Cape seed and book suppliers and is available from P.O. Box 23709, Claremont 7735, South Africa
} 
TABLE 1

Analyses of the 0 to $300 \mathrm{~mm}$ soil layer of the sandy and sandy loam soils in the Stellenbosch district, determined before the treatments commenced.

\begin{tabular}{lcccccccccccc}
\hline Soil texture & $\begin{array}{c}\text { Clay } \\
(\%)\end{array}$ & $\begin{array}{c}\text { Silt } \\
(\%)\end{array}$ & $\begin{array}{c}\text { Sand } \\
(\%)\end{array}$ & $\begin{array}{c}\mathrm{pH} \\
(\mathrm{KCl})\end{array}$ & $\begin{array}{c}\text { Electrical } \\
\text { conductivity } \\
(\mathrm{dS} / \mathrm{m})\end{array}$ & $\begin{array}{c}\text { Organic C } \\
(\%)\end{array}$ & $\begin{array}{c}\mathrm{P}(\text { Bray II }) \\
(\mathrm{mg} / \mathrm{kg})\end{array}$ & $\begin{array}{c}\mathrm{K} \text { (Bray II) } \\
(\mathrm{mg} / \mathrm{kg})\end{array}$ & \multicolumn{3}{c}{$\begin{array}{c}\text { Exchangeable cations } \\
(\mathrm{cmol}(+) / \mathrm{kg})\end{array}$} \\
\hline Sandy & 6 & 4 & 90 & 5.3 & 0.09 & 0.61 & 123 & 57 & 1.82 & 0.34 & 0.15 & 0.04 \\
Sandy loam & 19 & 14 & 67 & 6.6 & 0.17 & 0.47 & 9 & 90 & 3.96 & 0.71 & 0.24 & 0.04 \\
\hline
\end{tabular}

TABLE 2

The treatments applied for four consecutive seasons (2006/07 to 2009/10) on a sandy and a sandy loam soil in the Stellenbosch district.

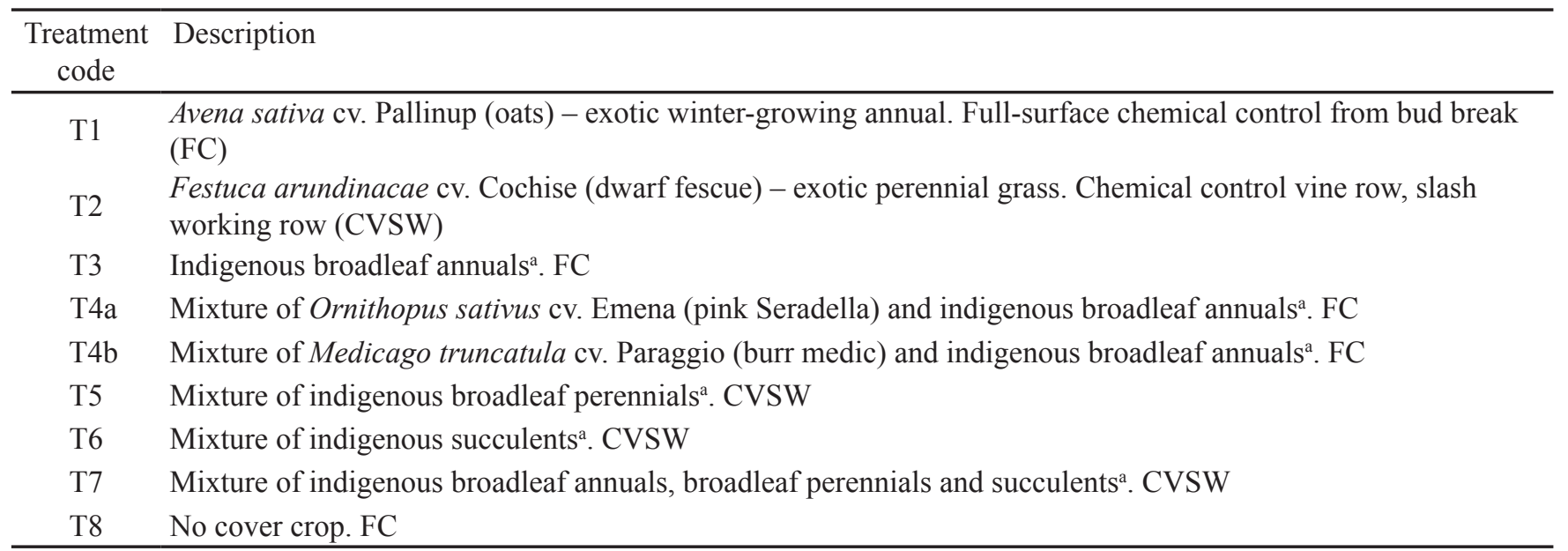

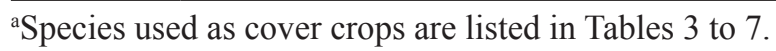

$1.5 \mathrm{~m}$ in the row and $2.75 \mathrm{~m}$ between rows and trained onto a double lengthened Perold trellis system (Booysen et al., 1992). Eight treatments (Table 2) were replicated three times in a fully randomised block design at both experimental sites. Individual plots (replications) covered an area of $81 \mathrm{~m}^{2}$ and were separated by two border grapevine rows and five border grapevines within rows.

Seedbed preparation was done to a depth of about $150 \mathrm{~mm}$ with a disc harrow (two pass-overs in opposite directions) in early March. The cover crops were sown annually during April (seeding dates varying between 4 and 24 April). After being sown by hand, the seeds were covered using a rotary harrow. The mechanical cultivations during seedbed preparation and the covering of the seeds were sufficient to eliminate the existing weeds. The $\mathrm{N}$-fixing cover crops were inoculated with the appropriate Rhizobium leguminosarum strains just before being sown. From the 2008/09 season onwards, the fynbos and renosterveld seeds were soaked in a germination stimulant (Cape seed primer ${ }^{\circledR}$ ) for 24 hours. Depending on the rainfall, irrigation was applied weekly from April to May and fortnightly from June to August by means of $25 \mathrm{~L} / \mathrm{h}$ micro-sprinklers with a $360^{\circ}$ wetting pattern that covered the whole surface, according to the guidelines supplied by Fourie et al. (2001). From September to March, the vineyards were irrigated according to the irrigation strategies of the farms on which the trial sites were situated. According to the norms proposed by Conradie (1994), sufficient amounts of $\mathrm{P}$ and $\mathrm{K}$ to sustain grapevine growth were available in the sandy soil and the sandy loam soil respectively (Table 1). All the cover crops received $28 \mathrm{~kg} / \mathrm{ha}$ $\mathrm{N}$ at the two- to six-leaf stages of the grass cover crops, while only the sandy soil received $30 \mathrm{~kg} / \mathrm{ha} \mathrm{K}$. The sandy loam soil received $15 \mathrm{~kg} / \mathrm{ha} \mathrm{P}$ just before seedbed preparation to encourage cover crop growth, while no $\mathrm{P}$ was applied on the sandy soil, in which the levels (Table 1) already exceeded the norm (Conradie, 1994). Post-emergence weed control in the vine row was achieved with glyphosate at a rate of $1.44 \mathrm{~kg} / \mathrm{ha}$ (active ingredient). From the 2008/09 season onwards, a selective post-emergence herbicide that controls annual and perennial grasses, namely fluasifop-p-butyl, was applied at a rate of $0.63 \mathrm{~kg} / \mathrm{ha}$ (active ingredient) during early June in the treatments in which the fynbos and renosterveld species were sown as cover crops (T3, T5, T6 and T7). This was done to reduce the competition between these species and the winter-growing grass weeds.

\section{Indigenous species employed as cover crops}

The indigenous species established as cover crops in the different treatments are listed in Tables 3 to 7. These species were selected mainly for their decumbent growth habit and soft seed coats. The seeds were not commercially available and were gathered in the veld during the previous spring (September/October). Therefore, availability also played an important role in the choice of species. As a result, the spectrum of species that qualified on the basis of the abovementioned criteria varied between years. Seed availability limited the seeding density in 2006/07 to between 10 and 15 seeds $/ \mathrm{m}^{2}$, after which it was increased tenfold in 
2007/08 to $100 \mathrm{seeds} / \mathrm{m}^{2}$ (Tables 3 to 7 ). From the 2008/09 season onwards, a seeding density of 300 seeds $/ \mathrm{m}^{2}$ was maintained, which corresponded to the densities employed for commercial cover crops.

\section{Measurements}

\section{Soil chemical analyses}

Soil samples were taken from the 0 to $75 \mathrm{~mm}, 75$ to 150 and 150 to $300 \mathrm{~mm}$ soil layers in all the plots (replications) at the start of the trial. The soil was sampled from three positions for each layer in approximately the middle of the work row.
The composite samples were analysed for $\mathrm{pH}(1.0 \mathrm{M} \mathrm{KCl})$, electrical conductivity, $\mathrm{P}$ and $\mathrm{K}$ (Bray II), exchangeable $\mathrm{K}, \mathrm{Ca}$, $\mathrm{Mg}$ and $\mathrm{Na}$, and organic carbon. The electrical conductivity $\left(\mathrm{EC}_{\mathrm{e}}\right)$ was determined by saturating the soil samples with deionised water, filling a US Bureau of Soil Standards electrode cup with the saturated paste and measuring the $\mathrm{EC}_{\mathrm{e}}$ with a conductivity meter. The samples for the determination of $\mathrm{P}$ and $\mathrm{K}$ were prepared according to the Bray II method (The Non-affiliated Soil Analysis Work Committee, 1990), while the exchangeable cations were extracted with a $1 \mathrm{M}$ ammonium acetate solution. These samples were analysed

TABLE 3

Indigenous broadleaf annuals included in treatment 3 (T3) at both experimental sites during the 2006/07, 2007/08, 2008/09 and 2009/10 seasons.

\begin{tabular}{lcccc}
\hline Species & \multicolumn{3}{c}{ Seeding density $\left(\mathrm{seeds} / \mathrm{m}^{2}\right)$} \\
\cline { 2 - 5 } & $2006 / 07$ & $2007 / 08$ & $2008 / 09$ & $2009 / 10$ \\
\hline Felicia heterophylla (Cass) Grau & 10 & 50 & 80 & 100 \\
Dimorphotheca pluvialis (L.) Moench & - & 50 & 220 & 100 \\
Scenecio elegans L. & - & - & - & 100 \\
Total & 10 & 100 & 300 & 300 \\
\hline
\end{tabular}

TABLE 4

Exotic and indigenous broadleaf annuals included in treatment 4 (T4a and T4b) at both experimental sites during the 2006/07, 2007/08, 2008/09 and 2009/10 seasons.

\begin{tabular}{lcccc}
\hline Species & \multicolumn{3}{c}{ Seeding density (seeds $\left./ \mathrm{m}^{2}\right)$} \\
\cline { 2 - 5 } & $2006 / 07$ & $2007 / 08$ & $2008 / 09$ & $2009 / 10$ \\
\hline Felicia heterophylla (Cass) Grau & 5 & 25 & 40 & 50 \\
Dimorphotheca pluvialis (L.) Moench & - & 25 & 110 & 50 \\
Scenecio elegans L. & - & - & 50 \\
Ornithopus sativus cv. Emena (pink Seradella) $^{\mathrm{a}}$ & 300 & 300 & 300 & 300 \\
Medicago truncatula cv. Paraggio (burr medic) $^{\mathrm{b}}$ & 300 & 300 & 300 & 300 \\
Total per experimental site & 305 & 350 & 450 & 450 \\
\hline
\end{tabular}

${ }^{\mathrm{a}}$ Sown on the sandy soil only (T4a). ${ }^{\mathrm{b}}$ Sown on the sandy loam soil only (T4b).

TABLE 5

Indigenous broadleaf perennials included in treatment 5 (T5) at both experimental sites during the 2006/07, 2007/08, 2008/09 and 2009/10 seasons.

\begin{tabular}{|c|c|c|c|c|}
\hline \multirow[t]{2}{*}{ Species } & \multicolumn{4}{|c|}{ Seeding density (seeds $/ \mathrm{m}^{2}$ ) } \\
\hline & $2006 / 07$ & $2007 / 08$ & $2008 / 09$ & $2009 / 10$ \\
\hline Geranium incanum Burm.f. & 3 & - & - & 30 \\
\hline Hermannia pinnata L. & 3 & - & 50 & 30 \\
\hline Helichrysum petiolare Hilliard \& B.L. Burtt. & 3 & - & 15 & 30 \\
\hline Pelargonium capitatum (L.) L’Hér. & 3 & 20 & 30 & 30 \\
\hline Gazania krebsiana Less. & - & 15 & 50 & 30 \\
\hline Steirodiscus tagetes (L.) Schltr. & - & 25 & 25 & 30 \\
\hline Heliophyla coronopifolia L. $^{a}$ & - & 25 & 70 & 30 \\
\hline Lesertia frutescens (L.) Goldblatt \& J.C. Manning & - & 15 & 60 & 30 \\
\hline Roella ciliata L. & - & - & - & 30 \\
\hline Monopsis lutea (L.) Urb. & - & - & - & 30 \\
\hline Total & 12 & 100 & 300 & 300 \\
\hline
\end{tabular}

${ }^{\mathrm{a} A n}$ annual species 
with an ICP-OES spectrometer (PerkinElmer Optima 7300 DV, Waltham, Massachusetts, USA). The organic C content was determined by the Walkley-Black method (Walkley \& Black, 1934). The average values of the three layers are presented in Table 1.

\section{Soil physical analyses}

Soil samples were taken from the 0 to $300 \mathrm{~mm}$ soil layer of the sandy and sandy loam soils in March 2007, during the second season of the trial. For each soil type, the soil samples were taken at two randomly selected plots in each of the three blocks in which the treatments were replicated. In each plot the soils were sampled at three positions in the work row. The clay, silt and sand fractions of the three composite samples (each consisting of the soil from three positions $\mathrm{x}$ two plots) were determined according to the hydrometer method (Van der Watt, 1966). The average values are presented in Table 1. Soil texture was classified according to a texture chart (Soil Classification Working Group, 1991).

\section{Cover crop and weed dry matter production}

Dry matter production (DMP) by both the cover crops and the associated weeds was determined just before grapevine bud break (end of August), when the grapevine berries

TABLE 6

Indigenous broadleaf succulents included in treatment 6 (T6) at both experimental sites during the 2006/07, 2007/08, 2008/09 and 2009/10 seasons.

\begin{tabular}{lcccc}
\hline Species & \multicolumn{3}{c}{ Seeding density (seeds/ $\mathbf{m}^{2}$ ) } \\
\cline { 2 - 5 } & $2006 / 07$ & $2007 / 08$ & $2008 / 09$ & $2009 / 10$ \\
\hline Cleretum bellidiforme (Burm.f.) Rowley & 6 & 50 & 110 & - \\
Lapranthus multiradiatus (Jacq.) N.E. Br. & 6 & 25 & 85 & - \\
Drosanthemum striatum (Haw) Schwantes & 3 & 25 & 35 & - \\
Drosanthemum speciosum (Haw) Schwantes & - & - & 35 & - \\
Drosanthemum floribundum (Haw) Schwantes & - & - & 35 & - \\
Dimorphotheca pluvialis (L.) Moench & & & & 300 \\
Total & 15 & 100 & 300 & 300 \\
\hline
\end{tabular}

aThis indigenous broadleaf annual replaced the succulents that failed to establish themselves successfully for three consecutive years, in order to determine the potential of the broadleaf annual to be employed as a monoculture.

\section{TABLE 7}

Indigenous broadleaf perennials, succulents and broadleaf annuals included in treatment 7 (T7) at both experimental sites during the 2006/07, 2007/08, 2008/09 and 2009/10 seasons.

\begin{tabular}{lcccc}
\hline Species & \multicolumn{3}{c}{ Seeding density (seeds/m²) } \\
\cline { 2 - 5 } & $2006 / 07$ & $2007 / 08$ & $2008 / 09$ & $2009 / 10$ \\
\hline Geranium incanum Burm.f. & 1 & - & & 20 \\
Hermannia pinnata L. & 2 & - & 20 & 20 \\
Helichrysum petiolare Hilliard \& B.L. Burtt. & 2 & - & 20 & 20 \\
Pelargonium capitatum (L.) L'Hér. & 1 & 10 & 20 & 20 \\
Gazania krebsiana Less. & - & 10 & 20 & 20 \\
Steirodiscus tagetes (L.) Schltr. & - & 12 & 15 & 20 \\
Heliophyla coronopifolia L. & - & 12 & 30 & 20 \\
Lesertia frutescens (L.) Goldblatt \& J.C. Manning & - & 8 & 25 & 20 \\
Roella ciliata L. & - & - & - & 20 \\
Monopsis lutea (L.) Urb. & - & - & - & 20 \\
Cleretum bellidiforme (Burm.f.) Rowley & 4 & 24 & 50 & - \\
Lapranthus multiradiatus (Jacq.) N.E. Br. & 2 & 12 & 40 & - \\
Drosanthemum striatum (Haw) Schwantes & 3 & 12 & 20 & - \\
Drosanthemum speciosum (Haw) Schwantes & - & - & 20 & - \\
Drosanthemum floribundum (Haw) Schwantes & - & - & 20 & - \\
Felicia heterophylla (Cass) Grau & - & - & - & 30 \\
Dimorphotheca pluvialis (L.) Moench & - & - & - & 40 \\
Scenecio elegans L. & - & - & - & 30 \\
Total & 15 & 100 & 300 & 300 \\
\hline
\end{tabular}


reached pea size (end of November) and just before harvest (end of January), according to the procedure described by Fourie et al. (2001).

\section{Statistical procedures}

The experiment was a complete randomised block design with eight treatments replicated three times. The experiment was repeated for four consecutive seasons (years). DMP was measured randomly within each experimental plot at the end of August. The data were tested for normality (Shapiro \& Wilk, 1965), found to be acceptably normally distributed, and subjected to analysis of variance. Analyses of variance were performed for each season separately, using SAS (SAS, 1990). Student's $t$ least significant difference (LSD) was calculated at the 5\% and 10\% significance level to facilitate comparison between treatment means.

\section{RESULTS AND DISCUSSION \\ Cover crop performance and control of winter-growing weeds \\ 2006/07 season}

A mixture of indigenous broadleaf annuals (T3), a mixture of indigenous broadleaf perennials (T5) and a mixture of indigenous broadleaf annuals, broadleaf perennials and succulents (T7) established poorly on the sandy soil (Table 8). The mixture of indigenous succulents (T6), however, failed to become established. The weed stand measured in the treatment in which no cover crop was established (T8, control) (Table 9) was similar to that reported by Fourie et al. (2006) for a sandy loam soil near Stellenbosch. It therefore is suggested that this could be the level of weed competition a cover crop should be able to contend with in order to establish itself successfully in this region. The DMP of Avena sativa L. cv. Pallinup (oats) (T1) was higher than that of the other cover crop treatments (T2, T3, T4a, T5, T6

TABLE 8

Dry matter production (DMP) of exotic and indigenous cover crop species and mixtures of species on a sandy soil in the Stellenbosch district measured at the end of August during the 2006/07, 2007/08, 2008/09 and 2009/10 seasons.

\begin{tabular}{|c|c|c|c|c|}
\hline \multirow[t]{2}{*}{ Treatment } & \multicolumn{4}{|c|}{$\operatorname{DMP}(\mathrm{t} / \mathrm{ha})$} \\
\hline & $2006 / 07$ & $2007 / 08$ & $2008 / 09$ & $2009 / 10$ \\
\hline T1. Avena sativa L. cv. Pallinup (oats), FC ${ }^{\mathrm{a}}$ & 4.00 & 2.22 & 3.39 & 5.77 \\
\hline T2. Festuca arundinacae L. cv. Cochise (dwarf fescue), CVSW & 0.90 & 0.92 & 0.38 & 1.03 \\
\hline T3. Indigenous broadleaf annuals, FC & 0.90 & 0.35 & 1.43 & 1.14 \\
\hline $\begin{array}{l}\text { T4a. Ornithopus sativus L. cv. Emena (pink Seradella)/indigenous } \\
\text { broadleaf annuals mixture, FC }\end{array}$ & 1.90 & 4.00 & 3.20 & 2.63 \\
\hline T5. Mixture of indigenous broadleaf perennials, CVSW & 0.40 & 0 & 0.02 & 0.02 \\
\hline T6. Mixture of indigenous succulents ${ }^{\mathrm{c}}, \mathrm{CVSW}$ & 0 & 0.53 & 0.01 & 0.59 \\
\hline T7. Mixture of all indigenous species, CVSW & 0.30 & 0.18 & 0.26 & 0.11 \\
\hline T8. No cover crop, FC (control) & 3.90 & 3.87 & 1.01 & 2.95 \\
\hline $\operatorname{LSD}(p \leq 0.05)$ & 0.90 & 1.61 & 1.14 & 0.94 \\
\hline
\end{tabular}

${ }^{\mathrm{a}}$ Full-surface chemical control from bud break. ${ }^{\mathrm{b}}$ Chemical control vine row, slash working row. ${ }^{\mathrm{c}}$ During the $2009 / 10$ season the mixture of indigenous succulents was replaced with the indigenous broadleaf annual Dimorphotheca pluvialis (L.) Moench.

TABLE 9

Weed dry matter production (DMP) on a sandy soil at Boschendal farm near Stellenbosch measured at the end of August during the 2006/07, 2007/08, 2008/09 and 2009/10 seasons.

\begin{tabular}{|c|c|c|c|c|}
\hline \multirow[t]{2}{*}{ Treatment } & \multicolumn{4}{|c|}{$\operatorname{DMP}(\mathrm{t} / \mathrm{ha})$} \\
\hline & $2006 / 07$ & $2007 / 08$ & $2008 / 09$ & $2009 / 10$ \\
\hline T1. Avena sativa L. cv. Pallinup (oats), FC ${ }^{\mathrm{a}}$ & 1.20 & 2.35 & 0.17 & 0.13 \\
\hline T2. Festuca arundinacae L. cv. Cochise (dwarf fescue), CVSW & 4.50 & 3.26 & 1.23 & 0.93 \\
\hline T3. Indigenous broadleaf annuals, FC & 5.10 & 3.96 & 0.51 & 1.14 \\
\hline $\begin{array}{l}\text { T4a. Ornithopus sativus L. cv. Emena (pink Seradella)/ } \\
\text { indigenous broadleaf annuals mixture, FC }\end{array}$ & 2.60 & 1.37 & 0.14 & 0.24 \\
\hline T5. Mixture of indigenous broadleaf perennials, CVSW & 4.70 & 4.08 & 0.80 & 2.60 \\
\hline T6. Mixture of indigenous succulents ${ }^{\mathrm{c}}, \mathrm{CVSW}$ & 3.60 & 4.27 & 1.67 & 1.21 \\
\hline T7. Mixture of all indigenous species, CVSW & 4.90 & 3.63 & 1.28 & 1.51 \\
\hline T8. No cover crop, FC (control) & 3.90 & 3.87 & 1.01 & 2.95 \\
\hline $\operatorname{LSD}(p \leq 0.10)$ & $\mathrm{NS}^{\mathrm{d}}$ & 1.51 & NS & 1.64 \\
\hline
\end{tabular}

${ }^{\mathrm{a}}$ Full-surface chemical control from bud break. ${ }^{\mathrm{b}} \mathrm{Chemical}$ control vine row, slash working row. ${ }^{\mathrm{c}}$ During the $2009 / 10$ season the mixture of indigenous succulents was replaced with the indigenous broadleaf annual Dimorphotheca pluvialis (L.) Moench. ${ }^{\mathrm{d}}$ Data did not differ significantly at the $10 \%$ level. 
and T7) (Table 8) and similar to that reported by Fourie et al. (2006). The weed stand in T1 was $69 \%$ less than that of the control, which indicated that the oats tended to suppress the winter-growing weeds (Table 9). The DMP of the Ornithopus sativus L. cv. Emena (pink Seradella)/indigenous broadleaf annuals mixture (T4a) was higher than that of T3, suggesting that pink Seradella was the major contributor to the dry matter produced in T4a (Table 8). The weed stand in T4a was $34 \%$ less than that of the control (T8), indicating that this broadleaf cover crop mixture had the potential to suppress the winter-growing weeds as well. The exotic perennial grass Festuca arundinacae L. cv. Cochise (dwarf fescue) established in T2 produced less than a ton of dry matter per hectare (Table 8 ), which is below $50 \%$ of that reported for the same species established on a sandy clay loam soil in the Breede River Valley (Fourie, 2010). This perennial grass did not compete with the winter-growing weeds (Table 9).

Oats (T1) and the Medicago truncatula Gaertn. cv.
Paraggio (burr medic)/indigenous broadleaf annuals mixture (T4b) were the only cover crops that became established on the sandy loam soil (Table 10). The DMP in these two treatments was similar to that produced on the sandy soil (Table 8) and that reported by Fourie et al. (2006). The weed dry matter in $\mathrm{T} 1$ and $\mathrm{T} 4 \mathrm{~b}$ was $69 \%$ and $57 \%$ less than that of the control respectively (Table 11). This reduction in the weed dry matter indicated that these cover crops competed with the winter-growing weeds. The dry matter produced in T4b was attributed mainly to burr medic, which was similar to the trend observed for pink Seradella in T4a.

The overall poor performance of the indigenous species was attributed to, inter alia, a low seeding density (10 seeds $/ \mathrm{m}^{2}$ ) and the prolific weed growth at both sites (Tables 9 and 11). The winter-growing weed spectrum was evaluated visually. It was observed that the Lolium species and Bromus diandrus Roth. (ripgut brome) were the dominant grass species, while Raphanus raphanistrum L. (wild

TABLE 10

Dry matter production (DMP) of the exotic and indigenous cover crop species and mixtures of species on a sandy loam soil at Nietvoorbij experimental farm near Stellenbosch measured at the end of August during the 2006/07, 2007/08, 2008/09 and 2009/10 seasons.

\begin{tabular}{|c|c|c|c|c|}
\hline \multirow[t]{2}{*}{ Treatment } & \multicolumn{4}{|c|}{$\operatorname{DMP}(\mathrm{t} / \mathrm{ha})$} \\
\hline & $2006 / 07$ & $2007 / 08$ & $2008 / 09$ & $2009 / 10$ \\
\hline T1. Avena sativa L. cv. Pallinup (oats), FC & 3.90 & 6.15 & 3.12 & 1.99 \\
\hline T2. Festuca arundinacae L. cv. Cochise (dwarf fescue), CVSW & 0 & 1.86 & 0.51 & 0.97 \\
\hline T3. Indigenous broadleaf annuals, FC & 0 & 0 & 0.60 & 0.60 \\
\hline $\begin{array}{l}\text { T4b. Medicago truncatula Gaertn. cv. Paraggio (burr medic)/ } \\
\text { indigenous broadleaf annuals mixture, FC }\end{array}$ & 1.60 & 0 & 0.98 & 1.17 \\
\hline T5. Mixture of indigenous broadleaf perennials, CVSW & 0 & 0.24 & 0.09 & 0.04 \\
\hline T6. Mixture of indigenous succulents ${ }^{\mathrm{c}}, \mathrm{CVSW}$ & 0 & 0 & 0 & 0.74 \\
\hline T7. Mixture of all indigenous species, CVSW & 0 & 0 & 0.13 & 0.07 \\
\hline T8. No cover crop, FC (control) & 4.60 & 2.85 & 1.21 & 1.59 \\
\hline $\operatorname{LSD}(p \leq 0.05)$ & 1.60 & 1.46 & 0.92 & 0.79 \\
\hline
\end{tabular}

${ }^{\mathrm{a}}$ Full-surface chemical control from bud break. ${ }^{\mathrm{b}}$ Chemical control vine row, slash working row. ${ }^{\mathrm{c}}$ During the $2009 / 10$ season the mixture of indigenous succulents was replaced with the indigenous broadleaf annual Dimorphotheca pluvialis (L.) Moench.

\section{TABLE 11}

Weed dry matter production (DMP) on a sandy loam soil at Nietvoorbij experimental farm near Stellenbosch measured at the end of August during the 2006/07, 2007/08, 2008/09 and 2009/10 seasons.

\begin{tabular}{|c|c|c|c|c|}
\hline \multirow[t]{2}{*}{ Treatment } & \multicolumn{4}{|c|}{$\operatorname{DMP}(\mathrm{t} / \mathrm{ha})$} \\
\hline & $2006 / 07$ & $2007 / 08$ & $2008 / 09$ & $2009 / 10$ \\
\hline T1. Avena sativa L. cv. Pallinup (oats), $\mathrm{FC}^{\mathrm{a}}$ & 1.90 & 0.77 & 0.23 & 0.46 \\
\hline T2. Festuca arundinacae L. cv. Cochise (dwarf fescue), CVSW & 3.90 & 1.88 & 0.68 & 0.18 \\
\hline T3. Indigenous broadleaf annuals, FC & 4.30 & 2.96 & 0.66 & 0.73 \\
\hline $\begin{array}{l}\text { T4b. Medicago truncatula Gaertn. cv. Paraggio (burr medic)/ } \\
\text { indigenous broadleaf annuals mixture, FC }\end{array}$ & 2.00 & 2.05 & 0.26 & 0.70 \\
\hline T5. Mixture of indigenous broadleaf perennials, CVSW & 4.20 & 3.38 & 0.96 & 0.94 \\
\hline T6. Mixture of indigenous succulents ${ }^{c}$, CVSW & 4.70 & 3.06 & 0.90 & 0.55 \\
\hline T7. Mixture of all indigenous species, CVSW & 4.10 & 3.54 & 0.74 & 1.33 \\
\hline T8. No cover crop, FC (control) & 4.60 & 2.85 & 1.21 & 1.59 \\
\hline $\operatorname{LSD}(p \leq 0.05)$ & 1.90 & $1.41^{\mathrm{d}}$ & $\mathrm{NS}^{\mathrm{e}}$ & NS \\
\hline
\end{tabular}

${ }^{\mathrm{a}} \mathrm{FC}=$ full-surface chemical control from bud break. ${ }^{\mathrm{b}} \mathrm{CVSW}=$ chemical control vine row, slash working row. ${ }^{\mathrm{D}} \mathrm{During}$ the 2009/10 season the mixture of indigenous succulents was replaced with the indigenous broadleaf annual Dimorphotheca pluvialis (L.) Moench. ${ }^{\mathrm{d}}$ Data differed significantly at the $10 \%$ level. ${ }^{\mathrm{e}}$ Data did not differ significantly at the $10 \%$ level. 
radish), Picris echioides L. (bristly ox-tongue) and Sonchus oleraceus (L.) Hill (sowthistle) were the dominant broadleaf species on the sandy soil at Boschendal farm. On the sandy loam soil at Nietvoorbij research farm, it was observed that the Lolium species, Bromus unioloides HBK. (rescue grass) and Eragrostis species (lovegrass) were the dominant grass species, while Plantago lanceolata (narrow-leaved ribwort),

Erodium moschatum (L.) L'Hér. ex Ait. (musk heron's bill) and Echium plantagineum L. (purple Echium) were the dominant broadleaf species. Most of the above-mentioned species have an upright growth habit and grow prolifically after germination, which makes them aggressive competitors for space, water and nutrition.

\section{7/08 season}

The indigenous cover crops established themselves on the sandy soil, except for those in T5 (Table 8). However, the indigenous species in $\mathrm{T} 3, \mathrm{~T} 6$ and $\mathrm{T} 7$ still did not produce significant amounts of dry matter (Table 8 ). This was again attributed to the prolific weed growth (Table 9), which appears to be characteristic of the region (Fourie et al., 2006). Although the seeding density for the indigenous species compared favourably with that of Vicia dasycarpa, a species currently used commercially as a cover crop (Fourie, unpublished data), the percentage viability of the field-harvested seeds may have been lower. Despite the fact that the oats (T1) produced approximately 45\% less dry matter than in the previous season (Table 8), the stand of winter-growing weeds was less $(39 \%)$ than that of the control (Table 9). The improved cover crop growth observed in T4a (Table 8 ) resulted in the weed dry matter being less $(65 \%)$ than that of the control (Table 9). As in the case of the 2006/07 season, the cover crop dry matter produced in T4a was attributed mainly to pink Seradella.

On the sandy loam soil the weeds grew less prolifically than in the previous season (Table 11). This probably allowed the dwarf fescue to establish itself successfully in T2 (Table 10). The dry matter produced by this species was similar to the amounts reported by Fourie (2010) for a sandy clay loam soil in the Breede River Valley. The oats (T1) produced 58\% more dry matter than in the previous season (Table 10), which resulted in the winter-growing weeds being suppressed substantially (73\%) compared to the control. In contrast to the 2006/07 season, the burr medic/indigenous broadleaf annuals mixture (T4b) failed to become established. The reason for this is not clear.

Over and above the competition from winter-growing weeds and the seeding density still being too low (100 seeds per $\mathrm{m}^{2}$ compared to between 120 and 667 seeds per $\mathrm{m}^{2}$ employed for commercial cover crops), factors such as varying seed quality of the field-harvested seeds, predation by seed-eating fauna and a lack of sufficient external stimuli for the seeds to germinate (seeds of fynbos and renosterveld species need smoke as a chemical stimulant) could also have had a negative impact on the performance of the indigenous species.

\section{8/09 season}

Similarly to the 2007/08 season, the indigenous cover crops did not become established successfully, with the amounts of dry matter produced in T5, T6 and T7 still being insignificant (Table 8). The DMP of T3 increased from $0.35 \mathrm{t} / \mathrm{ha}$ in the $2007 / 08$ season to $1.43 \mathrm{t} /$ ha in the $2008 / 09$ season. This was attributed, inter alia, to the increased seeding density and the application of a post-emergence herbicide that selectively controlled the annual and perennial grasses in early June, reducing competition from the winter-growing weeds (Table 9). In contrast to the $2007 / 08$ season, the dwarf fescue (T2) performed poorly (Table 8). The cover crops in T1 and T4a produced acceptable amounts of dry matter (Table 8). Although the weed stand in T1 and T4a did not differ significantly from that of the control (T8), the wintergrowing weeds were reduced effectively (less than $20 \%$ of that in the control) (Table 9).

Despite an increase in seeding density, chemical control of the winter-growing grass weeds and treatment of the seeds with a germination stimulant, the indigenous species in T3, T5 and T7 did not establish themselves successfully on the medium-textured soil (Table 10). The mixture of succulents in T6 failed to become established for the third consecutive year. Although the indigenous broadleaf annuals (T3) did produce more than half a ton of dry matter per hectare, it was less than half of the dry matter produced by the local weeds. The oats (T1) produced an acceptable amount of dry matter, thus controlling the winter-growing weeds effectively, albeit not significantly (Table 11). Although the cover crops in $\mathrm{T} 4 \mathrm{~b}$ produced less than one ton per hectare of dry matter (Table 10), the winter-growing weeds were reduced by $79 \%$ compared to the control (T8).

It was observed that the dominant species in the mixture of indigenous broadleaf annuals was Dimorphotheca pluvialis (L.) Moench. This species therefore was established as a monoculture in T6 during the 2009/10 season, replacing the indigenous succulents as cover crop.

\section{9/10 season}

As in the 2008/09 season, the perennial indigenous species did not establish themselves successfully on the sandy and sandy loam soils (Tables 8 and 10). None of the indigenous mixtures or monocultures produced acceptable levels of dry matter to be considered for cover crop management. This finding supports the results of the previous season. On the sandy soil, the weed dry matter observed in T3 and T6 were lower than that of the control (Table 9). This was attributed to the winter-growing grass weeds being controlled in these treatments in early June. Effective weed control on the sandy soil in $\mathrm{T} 1$ and T4a confirmed the trends observed during the previous season (Table 9). Dwarf fescue (T2) produced approximately one ton of dry matter per hectare (Table 8), which resulted in the winter-growing weeds being reduced effectively (less than $20 \%$ of that in the control) on the sandy soil. This species produced a similar amount of dry matter on the sandy loam soil, which tended to suppress the wintergrowing weeds effectively as well.

\section{Control of summer-growing weeds}

Due to the poor performance of the indigenous cover crop species throughout the study, no significant trends were observed in the data sampled at the end of November and at the end of January (data not shown). 


\section{CONCLUSIONS}

None of the indigenous renosterveld and lowland fynbos mixtures or monocultures had the ability to become established under the conditions prevalent in a commercial vineyard situated in the Stellenbosch district of the Coastal wine grape region, South Africa. This occurred even though the grass weeds were controlled chemically in early June (early winter), and despite the fact that the seeding densities were similar to that of the cover crops currently employed in South African vineyards. Although care was taken to choose species with soft seed coats, the viability of the field-harvested seeds was unknown and could have been exceptionally poor, despite being treated with a germination stimulant. The fynbos and renosterveld species evaluated in this trial therefore should not be considered for cover crop management on either sandy or medium-textured soils in the Coastal wine grape region.

\section{LITERATURE CITED}

Booysen, J.H., Steenkamp, J. \& Archer, E., 1992. Names of vertical trellising systems (with abbreviations). Wynboer September, 15.

Conradie, W.J., 1994. Vineyard fertilization. Proceedings of a workshop on vineyard fertilization, Nietvoorbij, 30 September, ARC-Fruit, Vine and Wine Research Institute, Private Bag X5026, 7599 Stellenbosch, South Africa.

Fourie, J.C., 2010. Soil management in the Breede River Valley wine grape region, South Africa. 1. Cover crop performance and weed control. S. Afr J. Enol. Vitic. 31, 14-21.
Fourie, J.C., Louw, P.J.E. \& Agenbag, G.A., 2001. Effect of seeding date on the performance of grasses and broadleaf species evaluated for cover crop management in two wine grape regions of South Africa. S. Afr. J. Plant Soil $18,118-127$.

Fourie, J.C., Louw, P.J.E. \& Agenbag, G.A., 2006. Cover crop management in a Chardonnay/99 Richter vineyard in the Coastal wine grape region, South Africa. 1. Effect of two management practices on selected grasses and broadleaf species. S. Afr. J. Enol. Vitic. 27, 167-177.

Goldblatt, P. \& Manning, P., 2012. Plants of the Greater Cape Floristic Region. 1: The Core Cape flora. Strelitzia 29. South African National Biodiversity Institute, Private Bag X101, 0001 Pretoria, South Africa.

SAS, 1990. SAS/STAT users guide, version 8, first edition, volume 2. SAS Institute Inc., Campus drive, Cary NC 27513.

Shapiro, S.S. \& Wilk, M.B., 1965. An analysis of variance test for normality (complete samples). Biometrika 52, 591-611.

Soil Classification Work Group, 1991. Soil classification - A taxonomic system for South Africa. Memoirs on Natural Agricultural Resources of South Africa No. 15, Dept. of Agric. Develop., Private Bag X144, 0001 Pretoria, South Africa.

The Non-Affiliated Soil Analysis Work Committee, 1990. Handbook of standard soil testing methods for advisory purposes. Soil Sci. Soc. South Africa, P.O. Box 30030, 0132 Sunnyside, South Africa.

Van der Watt, H.V.H., 1966. Improved tables and a simplified procedure for the soil particle size analyses by the hydrometer method. S. Afr. J. Agric. Sci. 9, 911-916.

Walkley, A. \& Black, I.A., 1934. An examination of the Degtjareff method for determining organic carbon in soils: Effect of variation in digestion conditions and of inorganic soil constituents. Soil Sci. 63, 251-263. 